\title{
Permanent flame-blunted monofilament of middle cerebral artery occlusion technique for ischemia stroke induction in animal models
}

\author{
Yetty Ramli, ${ }^{1}$ Ahmad S. Alwahdy, ${ }^{1}$ Mohammad Kurniawan, ${ }^{1}$ Berry Juliandi, ${ }^{2}$ Puspita E. Wuyung, ${ }^{3}$ \\ Yayi D.B. Susanto ${ }^{3}$ \\ ${ }^{1}$ Department of Neurology, Faculty of Medicine, Universitas Indonesia, Cipto Mangunkusumo National Hospital, Jakarta, Indonesia \\ 2 Department of Biology, Institut Pertanian Bogor, Bogor, Indonesia \\ ${ }^{3}$ Department of Pathology Anatomy, Faculty of Medicine, Universitas Indonesia, Cipto Mangunkusumo National Hospital, \\ Jakarta, Indonesia
}

\section{ABSTRAK}

Latar belakang: Tikus merupakan hewan coba yang paling sering digunakan untuk mempelajari strok iskemik. Oklusi arteri serebral media (OASM) menggunakan benang monofilamen secara intraluminal banyak digunakan, dengan keuntungan dan kerugian yang dimilikinya. Untuk oklusi permanen, kematian pada tikus lebih tinggi dibandingkan dengan oklusi sementara. Pada penelitian ini, kami menggunakan teknik oklusi permanen dengan monofilamen yang dimodifikasi dengan tujuan mengurangi angka kematian, sehingga dapat digunakan untuk memahami fase kronik strok iskemik.

Metode: Dilakukan OASM secara permanen pada tiga tikusjenis Sprague-Dawley. Monofilamen yang telah dipanaskan ujungnya dimasukkan melalui arteri karotis komunis. Konfirmasi infark dilakukan dengan pemeriksaan histopatologi dan pewarnaan hematoksilin eosin. Selanjutnya, dilakukan penilaian terhadap fungsi neurologis pasca-oklusi.

Hasil: Tiga tikus pasca-oklusi dievaluasi dengan waktu yang berbeda (48 jam, 72 jam, dan 3 minggu). Pada pemeriksaan histopatologi area infark dan peri-infark pada ketiga tikus menunjukkan gambaran red neurons, neutrofil spongiosis, dan edema perivaskular. Perubahan secara histopatologi menunjukkan spongiosis lebih dominan pada 3 minggu pasca-OASM. Di sisi lain, perubahan red neurons dan edema perivaskular pada tiga minggu pasca-OASM lebih sedikit dibandingkan pada 48 jam dan 72 jam pasca-OASM.

Kesimpulan: Monofilamen yang telah dimodifikasi dengan memanaskan bagian ujungnya memperlihatkan efikasi menghasilkan area infark. Keuntungan teknik ini adalah sangat mudah dimodifikasi dan tidak memerlukan biaya mahal. Keberhasilan membuat oklusi permanen tanpa angka mortalitas yang tinggi memberikan harapan untuk melakukan penelitian lebih lanjut dalam melihat efek terapi yang baru pada strok fase kronik.

\begin{abstract}
Background: Rat is the most frequently used animal for ischemic stroke studies. Recently, middle cerebral artery occlusion (MCAO) by introducing various types of surgical monofilament intraluminally has been widely used, with their advantages and disadvantages. For permanent occlusion, problems with mortality in rats are higher than transient. In this study, we used permanent occlusion using modified monofilament by flaming on its tip which may reduce mortality rate, so that chronic phase of stroke can be learned extensively.
\end{abstract}

Methods: Three male Sprague-Dawley rats underwent permanent MCAO. The flame-blunted monofilament was introduced through common carotid artery. Hematoxylin eosin histopathology confirmation and functional assessment post-stroke induction were then evaluated.

Results: Evaluation was conducted on 3 rats in different time post-stroke induction (48 hours, 72 hours, and 3 weeks). Using histopathological examination, the infarction was proved in all 3 rats showing red neurons, perivascular edema and neutrophil spongiosis, in infarct and peri-infarct area. The changes in histopathology showed spongiosis were more dominant in 3 week-post-MCAO rats. On the other hand, red neurons and perivascular edema were less compared to 48 and 72-hour-post-MCAO rats.

Conclusion: Flame-blunted monofilament showed its efficacy in producing infarct area. The advantages of this technique are easy to perform with simple and less expensive modification of the monofilament. Conducting successful permanent occlusion with less mortality rate will give chances to do further research on stroke in chronic phase and its effect on novel treatment.

Keywords: middle cerebral artery occlusion, monofilament, rat

pISSN: 0853-1773 • eISSN: 2252-8083 • http://dx.doi.org/10.13181/mji.v26i3.1645 • Med J Indones. 2017;26:183-9

- Received 07 Nov 2016 • Accepted 16 Jul 2017

Corresponding author: Ahmad S. Alwahdy, ule842002@yahoo.com

Copyright @ 2017 Authors. This is an open access article distributed under the terms of the Creative Commons Attribution-NonCommercial 4.0 International License (http://creativecommons.org/licenses/by-nc/4.0/), which permits unrestricted non-commercial use, distribution, and reproduction in any medium, provided the original author and source are properly cited. 
Rat is the most frequently used animal for ischemic stroke studies. ${ }^{1}$ A study of ischemic stroke with rat models showed a lot of data for understanding the process of cell or brain injury.,3 However, the relevance of most of these results to human condition remains questionable. ${ }^{4}$ Translation of drugs from the result of rat study to human has been disappointing. Another treatment option for ischemic stroke is reperfusion. This therapy has become the most beneficial strategy for improving neurological outcomes after ischemic stroke. ${ }^{5}$ However, recent data showed the benefits of reperfusion therapy was the best in terms of time, from symptoms onset less than 2 hours and became insignificant after 7.3 hours. ${ }^{6}$ Future research may focus on a model of ischemic stroke that allows the researchers to assess the advantages and disadvantages of reperfusion for improving the neurological outcome after ischemic stroke ${ }^{1}$ and the window period of the treatment or reversible cell injury; ${ }^{7}$ allows to assess the role of comorbid i.e. hypertension or diabetes or atherosclerosis on outcomes; ; ${ }^{1,3}$ allows to assess the magnitude of injury (infarct size) and area of infarct location that induced by certain models. ${ }^{8}$

There have been many efforts to develop techniques on how to make infarct in animal models which mimic human infarct result and its pathogenesis. Recently, middle cerebral artery occlusion (MCAO) by introducing various types of surgical monofilament intraluminally has been widely used with inconsistent results. ${ }^{9}$ The technique can be used as the model of permanent or transient occlusion..$^{10}$ Permanent occlusion can give more information to understand chronic phase of stroke, but with high mortality as its limitation. Guidelines for drug development recommend that once efficacy is established in rodents, studies are carried out in gyrencephalic species such as cats, pigs, and non-human primates before proceeding with the studies in man. It is generally considered ethically more acceptable to use rodents rather than higher mammals. The animal and maintenance costs are low, and the vascular anatomy is similar to man. Rodent neuroanatomy and the cascade of molecular mechanisms leading to ischemic cell death are well characterized. ${ }^{11}$

Unfortunately, in Indonesia, limitation of supporting tools is the major problem, as well as the cost. In this study, we used simple and less expensive modification of monofilament (flame- blunted) with coating in length approximately $1-1,5 \mathrm{~mm}$ which inserted permanently to give a solution for producing reproducible stroke model in chronic phase.

\section{METHODS}

Three male Sprague-Dawley rats weighing 250$300 \mathrm{~g}$ at the beginning underwent permanent middle carotid artery occlusion (MCAO). All the surgical instruments and materials performed under sterile conditions, and a magnifying glass (five times magnification) was used to perform this technique to be more accurate and to reduce unwanted mistakes. The rats were anesthetized with ketamine $(80 \mathrm{mg} / \mathrm{kg})$ and xylazine $(10 \mathrm{mg} /$ $\mathrm{kg}$ ) intraperitoneally. After that, they were turned to the supine position and fixed to the surgical table using an adhesive tape. A midline neck incision was performed, and the soft tissues over the trachea were retracted gently. The common carotid artery (CCA) was carefully isolated from the vagus nerve, and permanent knots were placed. The first bifurcation of CCA was identified, and then external carotid artery (ECA) was ligated. At the bifurcation, incision was done by using tip of the needle (30 gauge) to insert the monofilament, and permanent knots were placed just in front of the incision hole to avoid moving of the filament out of its track (figure 1). The flame-blunted monofilament (figure 2) was straightened and advanced carefully up to $17-20 \mathrm{~mm} .^{12}$

By flame-blunted monofilament, damaged of the blood vessels would be reduced along the insertion track due to blunted tips. Furthermore, tips of flame-blunted monofilament would be coated approximately $1-1,5 \mathrm{~mm}$ in length to prevent the occlusion of the hypothalamic artery and decrease the mortality rate. ${ }^{13}$ Pterygopalatine artery was identified to avoid misplacement of filament. Once filament insertion into the middle cerebral artery (MCA) was confirmed, the midline neck incision was sewed using surgical suture. To relieve pain and discomfort in the postoperative period, paracetamol was given $(15 \mathrm{mg} / \mathrm{kg})$ orally as soon as the rats were conscious. Moreover, they received $1.0 \mathrm{ml}$ saline intraperitoneally as volume replenishment after the surgery.

At the end point of the study, the animals were sacrificed 48 hours, 72 hours, and 3 weeks 

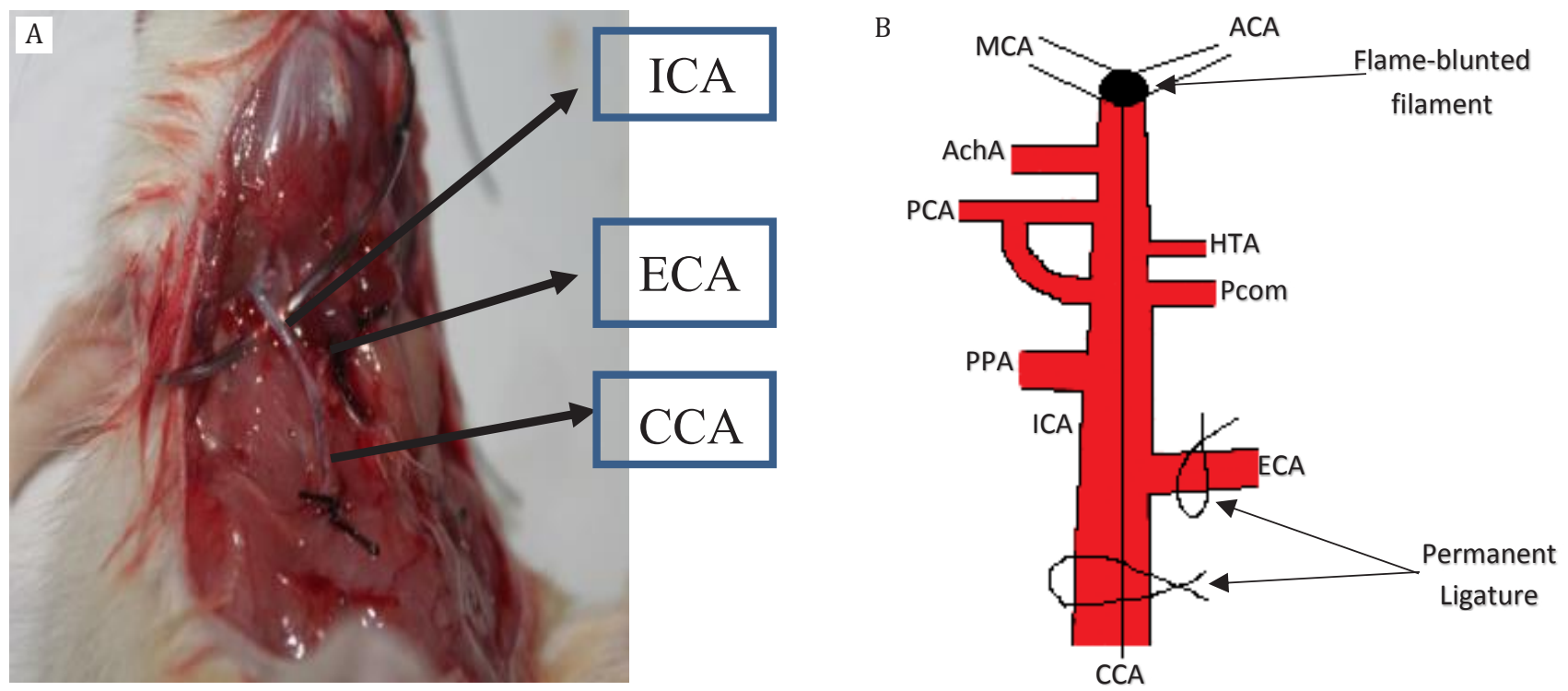

Figure 1. A) Permanent knots were placed in external carotid artery (ECA), and in common carotid artery (CCA) where the incision was made nearby the bifurcation of carotid; B) Illustration of flame-blunted monofilament in relation to cerebral vasculature. Internal carotid artery (ICA), pterygopalatine artery (PPA), middle cerebral artery (MCA), hypothalamic artery (HTA), posterior cerebral artery (PPA), and anterior choroidal artery (AchA)

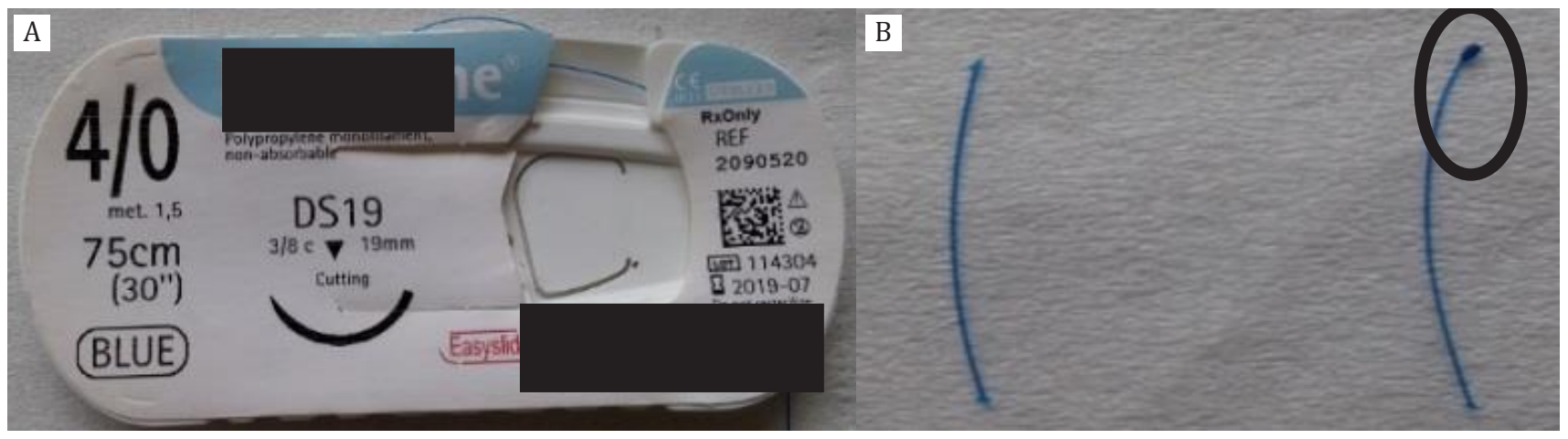

Figure 2. A) Monofilament; B) Flame-blunted monofilament marked by black circle (left side)

after permanent MCAO. Magnifying glass was used, including insertion of monofilament into middle cerebral artery. Haematoxilyn eosin histopathology confirmation and functional assessment post stroke induction were evaluated. Cylinder test was used to evaluate sensoric motor function and latency to move test to evaluate cognitive function. ${ }^{14,15}$

\section{Ethical issue}

This research has been approved by the research ethics of medicine/health, Medical Faculty of Universitas Indonesia with ethical approval number 789/UN2.F1/ETIK/2016.

RESULTS

After the rats were sacrificed, their brains were cut into $2 \mathrm{~mm}$ thickness from the bregma to the anterior part and stained with hematoxylin eosin. Under the microscope, we found infarct area in three rats where 48-hour and 72-hour post occlusion showed more red neurons compared to 3-week-stroke rat. For spongiosis, it was more dominant in the 3 weeks post MCAO compared to other rats. Macrophages were also found in acute (48 hours and 72 hours) rats, but we could not find in the 3 week-stroke-rat. Perivascular 
edema was more prominant in acute phase than in chronic phase of stroke (Figure 3).

Similarly to the functional assessment post stroke, three week-stroke-rats showed better progression compared to the others. It was correlated to the number of dead cells (red neurons) in rats. In cylinder test to evaluate the sensoric motor function, it showed that three week-stroke-rats started using the limb almost symetrically in vertical way. The 48 and 72 hour-rats were still using the healthy limb more dominant compared to the affected side (Figure 4a).
During evaluation of the cognitive function using latency to move test or spontaneous activity, the result was also similar with the motoric function test, three week-stroke-rats showed better result compared to the others.

\section{DISCUSSION}

Since many pathological changes in stroke and many factors have contributed in developing changes especially microscopically and recovery in stroke, MCAO in animal models of focal

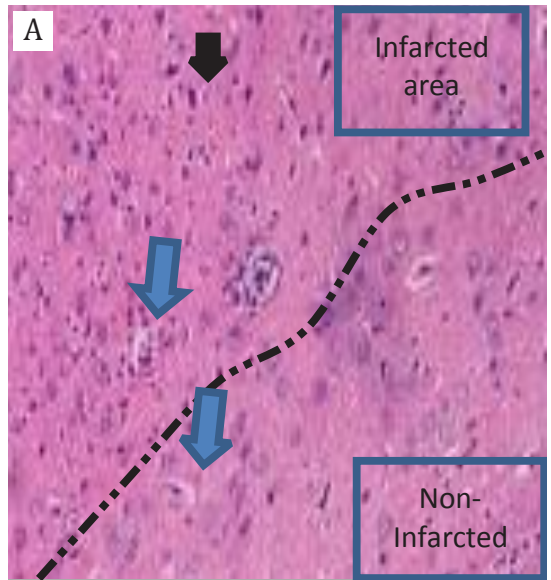

48 hours

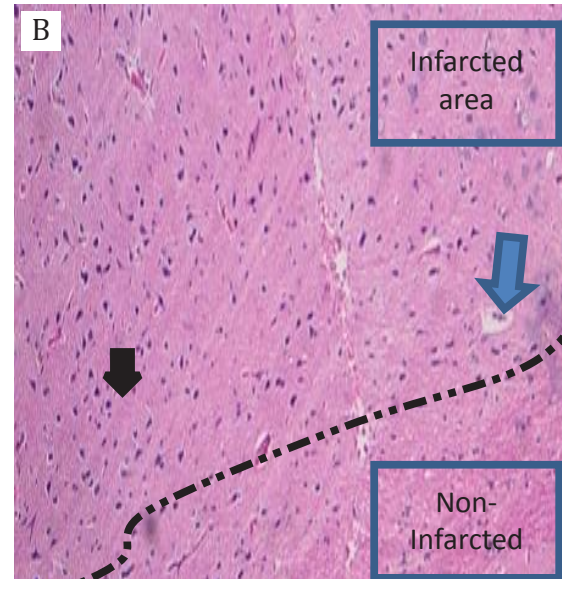

72 hours

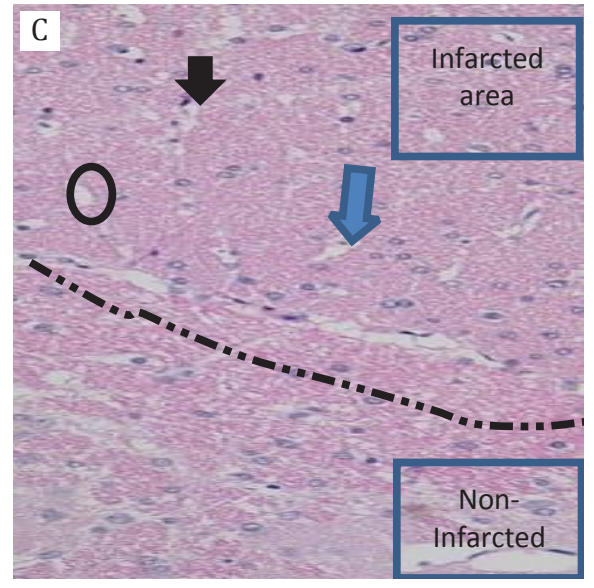

3 weeks

Figure 3. Histopathological changes in rats after MCAO induction. A) 48 hours after occlusion, showed dominant of red neurons (black arrow) using 10 times magnification; B) 72 hours after occlusion red neurons still dominant; C) Three weeks after occlusion, red neurons were decreased in number, but spongiosis (black circle) and perivascular edema (blue arrow) appeared more dominant using 20 times magnification. Interrupted line was the border area between infarct and non-infarct zone

A

Cylinder test

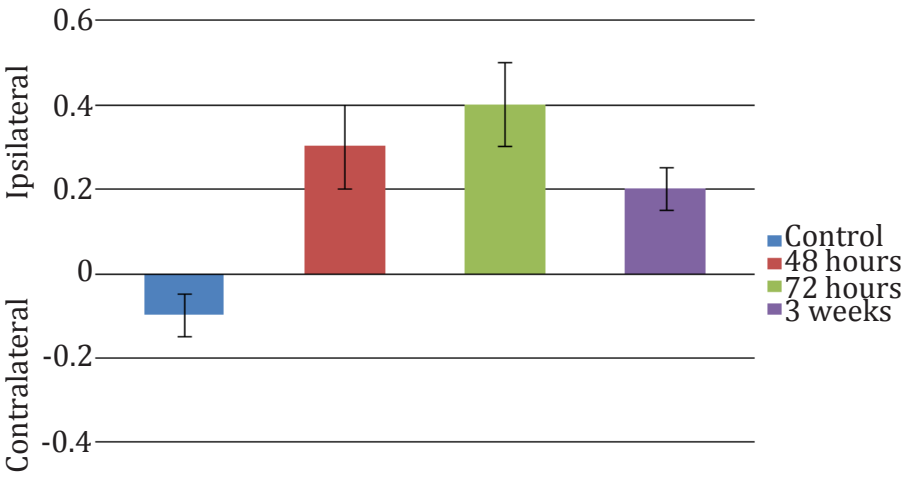

$-0.6$
B 25

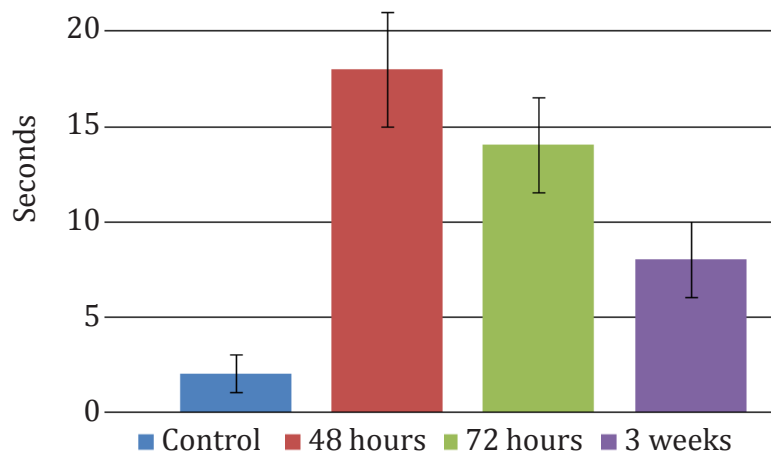

Figure 3. A) Cylinder test. Control rat using both extremities almost equally. Usage of non-affected side was increasing along the course of time (48 and 72 hours) after occlusion. Gradually, the rat will be using the affected side more often ( 3 weeks); B) Latency to move test. Control rat needs 2 secs to move. It reached its peaked after 48 hours (18 secs) after occlusion before gradually getting better afterward 
ischemia provide most evidence for cellular inflammatory responses in stroke. ${ }^{16}$ The obvious benefit for using this in vivo approach is that it allows for the study of ischemic insult on intact neuronal networks and the behavioral response post-insult, in addition to the neuroinflammatory processes that are present after ischemic damage. Therefore, this in vivo stroke model provides a critical complementary approach to in situ models that are used to mimic ischemia in cell culture. ${ }^{17}$ Moreover, it yields highly consistent results which minimize misleading interpretations, and hence, it is considered as a reliable stroke model to test a variety of neuroprotective drugs. Unfortunately, there are difficulties in determining border between acute and chronic stroke. ${ }^{16}$

Many techniques have been developed to produce brain infarct in animal models with their advantages and disadvantages. For the technique using craniectomy, it is associated with low or absent mortality since the craniectomy prevents increasing in intracranial pressure. ${ }^{11}$ Unfortunately, this technique needs surgical skill to reduce unsuccessful result. Tamura et $\mathrm{al}^{18}$ in 1981 performed an occlusion by using an electric current passed through the tips of fine diathermy forceps, with a good reproducibility in infarct size and functional deficit, low mortality, visual confirmation of successful MCAO.$^{18}$ On the other hand, exposing the artery and applying electro-coagulation without rupturing the blood vessel or damaging the underlying cortex was rather difficult. Alternatively, by using microaneurysm clips to occlude the artery was introduced. However, micro-aneurysm clips were too small to apply by hand in rats, and removing the clips without damaging the artery was technically difficult. ${ }^{19}$ For technique using blood clot occlusion, the advantage is that it closely mimics human ischemic stroke and is suitable for thrombolysis studies, but it would be less reproducible than other techniques. ${ }^{11}$ Since the beginning, in vitro studies demonstrated that rat's fibrinolytic system was 10 -fold less sensitive to thrombolysis agent than the human system. The dosage of thrombolysis agent might need to be increased, and it can cause hemorrhagic transformation. ${ }^{20}$

MCAO by the intraluminal suture method is currently the most widely used model of focal ischemia in rats and mice and is used to induce both permanent and transient ischemia. A flexible monofilament is introduced directly to the internal carotid artery (or with modification) and advanced until it blocks the origin of the MCA. Modifications were performed not only to improve reproducibility (include filament construction, coating and design of the tip), but also to reduce its complication. The advantages of this model are easier to master than the craniectomy models, and no craniectomy is required. ${ }^{11}$

Flame-blunted modification is the easiest way to modify the tip of the monofilament. By blunted the tips, damaged blood vessels would be reduced along the track of insertion. Furthermore, the relation between the length coating of the tip and the cerebral vasculature would influenced the result of infarction (Figure 1). Problems with morbidity and mortality are encountered when ischemia is permanent. This is manifested within the first 24-48 hours in animals with large MCA territory strokes due to brain swelling and increased intracranial pressure. ${ }^{11}$ If the infarct involves the hypothalamus, as seems to be frequently the case in animals subjected to permanent MCAO, hyperthermia may develop as a consequence of thermal dysregulation, leading to altered stroke outcome. ${ }^{21}$ Technical modifications and the use of standardized monofilaments can reduce the incidence of these complications. ${ }^{11}$

In this study, flame-blunted filaments have approximately $1-1,5 \mathrm{~mm}$ in length to coat the tip. Thus, it would occlude the MCA but not the AchA, PCA, and HTA totally. Furthermore, mortality can be reduced since HTA supply thalamus where thermoregulation are controlled. ${ }^{13}$ When the coating is more than $2 \mathrm{~mm}$ in length, blockage of HTA occurred and mortality is higher. Therefore, this method is suitable when permanent occlusion is needed for the study. Another advantage is that it gives hope to understand and to evaluate the effectiveness of the chronic stroke therapy in rats, where many experiments has failed due to higher mortality and complication in permanent occlusion. ${ }^{11,23}$

On the other hand, the disadvantages are mainly related to its complication since the size of the monofilament must be precise enough to block the blood flow, and it depends on rat's weight, age, and strain. Every technique purposely done depends on the aim of the study, where this 
technique it seems not suitable for thrombolysis rather than to study neuroprotective drugs and its mechanism. Nevertheless, the complication of this filament may have subarachnoid bleeding $(40 \%)^{22}$ and infarct size is not as wide as where the coating length of filament's tip more than 2 $\mathrm{mm} .^{13}$

Another disadvantage of this technique is that the confirmation of MCAO cannot be visualized. Successful occlusion is confirmed by the evidence of motor neurological deficit (supplementary video). ${ }^{24}$ Even though recently, MRI to assess the size of infarct is used worldwide, but the access to get MRI in Indonesia is still limited. Nevertheless, in this study we did not using immunohistochemistry staining nor angio and neurogenesis marker antibodies to evaluate histopathology changes for advance results.

We used a permanent MCAO technique where infarct area occurred more in the cortex area than striatum. On the other hand, if it was done by transient MCAO, the damage can reach the subcortical or striatum regions. ${ }^{12}$ Our study found similar results in which striatum in ipsilateral area was not affected; instead, it affected more in the cortical regions. It is very likely due to the transient cell damage caused by reperfusion. Therefore, it becomes more difficult to protect neuronal damage while in permanent delayed neuronal death occurred. ${ }^{12}$

Doing successful permanent occlusion provided knowledge about the opening and closing theory of blood-brain barrier in ischemic stroke which may occur up to 3-4 weeks. ${ }^{25}$ We demonstrated in this study that perivascular edema persisted at three-week post stroke, and that perivascular edema might be the evidence of disturbed blood brain barrier. Interestingly, functional recovery has achieved the improvement along time. This improvement correlated with reducing red neurons in infarct area, and it seems due to very well rats brain plasticity neurogenesis and angiogenesis had occurred. Good brain plasticity of rats will become a potential pitfall in evaluating the effectiveness of chronic stroke therapy in rats. The best time to give drugs based on this study is before the neurological deficits become recovered ( $<72$ hours) to decrease the bias effect of the treatment.
In conclusion, flame-blunted monofilament showed its efficacy in producing infarct area and not inferior to other type of other technique. The advantages of this technique is easy to perform with simple and less expensive modification of the monofilament. Performed a successful permanent occlusion by this technique without mortality, give chances to do more research for stroke in chronic phase and its effect on novel treatment in the future.

\section{Conflict of interest}

The authors affirm no conflict of interest in this study.

\section{Acknowledgment}

The first author acknowledges residency from the Department of Neurology, Universitas Indonesia. We thank to National Institute of Health Research and Development (litbangkes) Indonesia for providing animals laboratory and Department of Pathology Anatomy, Faculty of Medicine, Universitas Indonesia for assistance in histological analysis. This work has been funded by a grant from Universitas Indonesia "Hibah Publikasi Internasional Terindeks Untuk Tugas Akhir Mahasiswa UI 2016".

\section{REFERENCES}

1. Bacigaluppi M, Comi G, Hermann DM. Animal models of ischemic stroke. Part two; modelling cerebral ischemia. Open Neurol J. 2010;4:34-8.

2. Park SY, Marasini S, Kim GH, Ku T, Choi C, Park MY, et al. A method for generate a mouse model of stroke: evaluation of parameters for blood flow, behavior, and survival. Exp Neurobiol. 2014;23(1):104-14.

3. Kaya AH, Erdogan H, Tasdemiroglu E. Searching evidences of stroke in animal models: a review of discrepancies. Turk Neurosurg. 2016;27(2):167-73.

4. Casals JB, Pieri NCG, Feitosa MLT, Ercolin ACM, Roballo KCS, Barreto RSN, et al. The use of animal models for stroke research: a review. Comp Med. 2011;61(4):305-13.

5. Molina CA, Saver JL. Extending reperfusion therapy for acute Ischemic stroke. Emerging pharmacological, mechanical, and imaging stategies. Stroke. 2005;36:2311-20.

6. Saver JL, Goyal M, vander Lugt A, Menon BK, Majole CBLM, Dippel DW, et al. Time to treatment with endovascular thrombectomy and outcomes from Ischemic stroke: a meta-analysis. JAMA. 2016;316:1279-88.

7. Fluri F, Schuhmann MK, Kleinschnitz C. Animal models of Ischemic stroke and their application in clinical research. Drug Des Devel Ther. 2015;9:3445-54.

8. Canazza A, Minati L, Boffano C, Parati E, Binks S. Experimental models of brain ischemia: a review 
of techniques, magnetic resonance imaging, and investigational cell-based therapies. Front Neurol. 2014;5:1-9.

9. Longa, EZ, Weinstein PR, Carlson S, Cummins R. Reversible middle cerebral artery occlusion without craniectomy in rats. Stroke. 1989;20:84-91.

10. Chou WH., Choi DS, Zhang H, Mu D, McMahon T, Kharazia VN, et al. Neutrophil protein kinase Cdelta as a mediator of stroke-reperfusion injury. J Clin Invest. 2004;114:49-56.

11. Macrae IM. Preclinical stroke research-advantages and disadvantages of the most common rodent models of focal ischaemia. Br J Clin Pharmacol. 2011;164:1062-78.

12. Rupadevi M, Parasuraman S, Raveedran R. Protocol for middle cerebral artery occlusion by an intraluminal suture method. J Pharmacother. 2011;2:36-9.

13. Guan Y,Wang Y, Yuan F, Lu H, Ren Y, et al. Effect of Suture Properties on Stability of Middle Cerebral Artery Occlusion Evaluated by Synchrotron Radiation Angiography. Stroke. 2012;43:888-91.

14. Lubjuhn J, Gastens A, Von WG, Bargiotas P, Herrmann O, Murikinati S, et al. Functional testing in a mouse stroke model induced by occlusion of the distal middle cerebral artery. J Neurosci Methods. 2009;184:95-103.

15. Rosell A, Agin V, Rahman M, Morancho A, Ali C, Koistinaho J, et al. Distal occlusion of the middle cerebral artery in mice: Are we ready to assess long-term functional outcome? Transl Stroke Res. 2013;4:297-307.

16. Margatitescu O, Mogoanta L, Pirici I, Pirici D, Cernea D,l. Histopathological changes in acute ischemic stroke. Rom J Morphol Embryol. 2009;50:327-39.
17. Colak G, Fillano A J, Johnson GV. The application of permanent middle cerebral artery in the mouse. J Vis Exp. 2011;53:1-4.

18. Tamura A, Graham DI, McCulloch J, Teasdale GM . Focal cerebral ischemia in the rat: 1 . Description of technique and early neuropathological consequences following middle cerebral artery occlusion. J Cereb Blood Flow Metab. 1981;1:53-60.

19. Van Bruggen $N$, Thibodeaux H, Palmer JT, Lee WP, Fu L, Cairns B et al. VEGF antagonism reduces edema formation and tissue damage after ischemia/ reperfusion injury in the mouse brain. J Clin Invest. 1999;104:1613-20.

20. Kano T, Katayama Y, Tejima E, Lo EH. Hemorrhagic transformation after fibrinolytic therapy with tissue plasminogen activator in a rat thromboembolic model of stroke. Brain Res. 2000;854:245-8.

21. Li F, Omae F, Fisher M. Spontaneous hyperthermia and its mechanism in the intraluminal suture middle cerebral artery occlusion model of rats. Stroke. 1999;30:2464-70.

22. Herson PS., Traystman R. Animal model of stroke: translational potential at present and in 2050. Future Neurol. 2014;9:541-51.

23. Braeuninger S, Kleinschnitz C. Rodent models of focal cerebral ischemia: procedural pitfalls and translational problems._Exp Transl Stroke Med. 2009;1:8.

24. Guzel A, Rolz R, Nikkhah G, Kalert U.D, Maciaczyk J. A microsurgical procedure for middle cerebral artery occlusion by intraluminal monofilament insertion technique in the rat: a special emphasis on the methodology. Exp Transl Stroke Med. 2014;6:6.

25. Yi Yang, Gary A.R. Blood-brain barrier breakdown in acute and chronic cerebrovascular disease. Stroke. 2011;42:3323-8. 